\begin{tabular}{|c|}
\hline Veronica Stigger \\
(1973, Porto Alegre - RS) é escritora, jornalista, \\
crítica de arte e docente da Fundação Armando \\
Álvares Penteado (FAAP). De sua produção \\
recente destacam-se Sul, (Editora 34, 2016) \\
- vencedor do Prêmio Jabuti de 2017, na \\
categoria Contos e Crônicas - e Opisanie Swiata \\
(Cosac Naify, 2013). Foi curadora da exposição \\
Maria Martins: Metamorfoses (MAM-SP) e da \\
exposição de fotografias de Eduardo Viveiros \\
de Castro, Variações do corpo selvagem, com \\
Eduardo Sterzi. \\
E-mail: veronicastigger@gmail.com
\end{tabular}

\section{a pele}

Ele

sentia tamanha aversão a pelos que chegou a arrancálos todos de seu corpo com cera quente e pinça, não poupando nem mesmo os cílios e as sobrancelhas, nem mesmo os pelos de dentro do nariz, em favor de uma feição que fosse pura pele, a mais lisa, macia e imaculada pele, a qual hidratava três vezes ao dia com uma abundante camada do tradicional creme nívea da latinha chata e azul, creme branco e espesso que levava o mesmo nome de sua avó materna, morta centenária com a pele firme e elástica devido ao uso constante daquele creme que ela mandava vir da alemanha e que ele, anos depois, espalhava religiosamente sobre todo o corpo como se passasse a própria avó em sua pele, absorvendo pelos poros sua herança genética, sua mais arraigada tradição
Ele

ao colocar o relógio, numa tarde nevosa de agosto de mil novecentos e oitenta e quatro, viu um único pelo sobre o pulso esquerdo, um pelo grisalho, grosso, um tanto longo, irrompendo na pele com a violência de uma britadeira que furasse a terra de dentro para fora, e esta terrível descoberta o fez aproximar do pelo seus olhos de lupa (olhos míopes), notando, deste modo, que o poro de onde o pelo provinha estava vermelho e inchado, com uma minúscula ferida à esquerda, uma ferida sobre a qual ele não titubeou em passar a unha, acabando por arrancar, sem querer, a ínfima casquinha que, ao abrir um pouco mais a pequena lesão, liberou passagem para a saída de outro pelo, também grisalho, grosso, um tanto longo, que logo se ergueu majestoso ao lado do primeiro

Ele

- que sentia tamanha aversão a pelos que chegou a arrancá-los todos de seu corpo em favor de uma feição que fosse pura pele, a mais lisa, macia e imaculada pele - se horrorizou e tentou extirpar com os dedos mesmo aqueles dois estranhos, conseguindo com esta ação irracional e desesperada apenas levantar um pedaço da pele inflamada sob a qual se deixavam vislumbrar outros pelos grisalhos, grossos, um tanto longos, os quais também tentou arrancar com os próprios dedos igualmente sem sucesso e, quanto mais forçava o polegar e o indicador em pinça para dentro de sua pele, de onde não paravam de surgir indecorosos pelos, mais abria a ferida, uma ferida exangue, limpa e escura, como uma fenda na rocha indicando a entrada de uma caverna pré-histórica 
Ele

percebeu que seria inútil continuar tentando arrancar com os próprios dedos os pelos que emergiam de dentro de si e segurou com firmeza a pele rasgada pela ferida, levantando-a com cuidado como se quisesse descascar uma batata cozida de uma só vez ou como se retirasse um penso de um machucado ainda aberto e muito doído, e conforme ia puxando delicadamente a pele ia descobrindo uma mata de pelos grossos, grisalhos, um tanto longos que se apossavam sem qualquer cerimônia de seu braço esquerdo, e ele seguiu tirando a pele que hidratou com tanto esmero por tanto tempo, desvelando em seus braços, pernas, pés, tronco, pescoço, cabeça uma quantidade inimaginável de pelos que agora cobriam por inteiro seu mais novo corpo de lobo 